\title{
PIRMOJI LIETUVOS RESPUBLIKOS KARIUOMENĖS KARINĖ DOKTRINA IR JOS AUTORIUS
}

\author{
Dr. Vytautas Jokubauskas \\ Klaipedos universiteto Baltijos regiono istorijos ir archeologijos institutas
}

Lietuvos kariuomenès tyrimų kontekste tenka atversti naują jos istorijos puslapi ir pažvelgti ị teorinius tarpukario Lietuvos karininkų samprotavimus karybos klausimais. Vienas iš aspektų, atskleidžiančių planingą ir nuoseklią Lietuvos kariuomenès raidą, - pirmosios Lietuvos Respublikos kariuomenès karinė doktrina. Nubraukę laiko dulkes galime konstatuoti, kad vos nutilus artilerijos kanonadoms frontuose susirūpinta darnia kariuomenès raida: ji plètota priimant bendrus visoms pajejgoms komplektavimo, moralès, mokymo, aprūpinimo ir taktikos principus, kurie buvo suformuluoti atsižvelgiant $\mathfrak{i}$ kitų šalių armijų patirtị Pirmojo pasaulinio karo metu ir Lietuvos sąlygas. Galima kelti hipotezę, kad karineje doktrinoje itvirtintų nuostatų daugiau ar mažiau buvo laikomasi, jos buvo ịtvirtintos kariuomenès statutuose.

Karinè doktrina rengiama pajègas ruošiant ateities karui. Ją rengiant būtina plačiai išanalizuoti karo istorijos atvejus, ịvertinti galimus priešus, atsižvelgti i turimas technines priemones ir ginkluotę, nacionalinius ypatumus. Tokị platų ir kartu nuodugnų teorinị darbą galejo atlikti tik gerą karinị pasirengimą ir daug patirties turintis asmuo. Šiai užduočiai atlikti XX a. trečiojo dešimtmečio pradžioje Lietuvos kariuomenè daug kandidatų neturejjo. Kitose Europos šalyse štabo, planavimo ir kitų panašių sričių karininkai (pvz., doktrinoms kurti ir atnaujinti) buvo rengiami specialiose aukštosiose generalinio štabo akademijose. I jas buvo priimami gabiausi, karo tarnybos patirties turintys karininkai. Kai kada žargoniškai vadinti „genštabistais“, jie praktiškai buvo visų kariuomenių smegenys, bet Lietuvos kariuomenès kūrimosi ir kovų dèl nepriklausomybès laikotarpiu tokio lygio karininkų itin stokota. Iš esmès Lietuvos karininkų korpusas, kaip ir 
Latvijos bei Estijos, buvo formuojamas iš Rusijos imperijos armijos, kurios generalinio štabo karininkai buvo rengiami tik vienoje karo mokykloje Rusijos imperijos Nikolajaus generalinio štabo akademijoje, kuri kasmet visai imperijos armijai parengdavo iki šešiasdešimties absolventų, kadrų ${ }^{1}$. Kaip pavyzdi galima paminèti Latvijos ir Estijos kariuomenes, kuriose palyginti daug karininkų išsilavinimą igijo dar iki Pirmojo pasaulinio karo. 1907-1914 m. Rusijos kariuomenejje tarnavo apie 420-460 rikiuotès karininkų, iš jų pora dešimčių - studijavusių Rusijos imperijos Nikolajaus generalinio štabo akademijoje Sankt Peterburge, tarp kurių buvo Latvijos kariuomenès vadai gen. Dāvidas Sīmansonas, gen. Mārtiņis (Mārtiņš) Peniķis ir gen. Pēteris Valdemāras Radzinis (Radziņš), Latvijos karo ministras gen. Rūdolfas Bangerskis ir gen. E. Kalninis, Latvijos armijos štabo viršininkas gen. Mārtiņis (Mārtiņš) Hartmanis, pirmasis Latvijos kariuomenès generolas Augustas Ernestas Misiņis (Misiņš), gen. Jānis Buividas (Buivids) ir kt. ${ }^{2}$ Taigi Latvijos kariuomenejje buvo gana daug Rusijos Generalinio štabo akademijos auklètinių (33), Nepriklausomybès kovų metu tarp aukštųjų karininkų jie sudare 4,2 \% ${ }^{3}$. Estijos kariuomeneje tarnavo apie 2000 buvusių Rusijos imperijos armijos karininkų $u^{4}$. Estijos kariuomenès vadas gen. Johanas Laidoneris minètą Rusijos imperijos Generalinio štabo akademiją baige $1912 \mathrm{~m}$., šios akademijos absolventas buvo gen. Jaanas Sootsas (1913 m.) ir kai kurie kiti tarpukario Estijos kariuomenès generolai.

Galima teigti, kad tarpukariu Lietuvos kariuomenèje tarnavo vos keletas Rusijos armijos Generalinio štabo akademijos absolventų, vienas iš jų - gen. mjr. Leonas Radus-Zenkavičius, tarnybą Lietuvos kariuomenèje pradėjęs tik $1921 \mathrm{~m}$. vasarị. Tačiau generolas turèjo trijų dešimtmečių tarnybos Rusijos imperijos armijoje patirties, buvo 1904-1905 m. Rusijos-Japonijos ir Pirmojo pasaulinio karų dalyvis. L. Radus-Zenkavičius

1 Kiekvienų metų laidos absolventų sąrašus žr.: Русскаiа императорскаiа армиіа. [žr. 201308 22] < http://regiment.ru/reg/VI/A/1/3-8.htm\#1912 >.

2 Jēkabsons Ė. Latviešu tautības virsnieki Krievijas armijā 1907.-1913. gadā. Latvijas kara muzeja gadagrāmata, t. XIII, 2012, 1. 14-18, 32-33, 40-41.

3 Latvijas armijas augstākie virsnieki 1918-1940. Sas.: E. Jēkabsons; V. Ščerbinskis. Rīga, 1998, 1. 23-25, 39, 40, 98.

4 Traksmann A. Estų kariuomenès kariško auklejjimo ir mokymo pagrindiniai klausimai. Mūsǔ žinynas, 1933, t. XXIV, Nr. 97, p. 278. 
gimé $1874 \mathrm{~m}$. vasario $21 \mathrm{~d}$. (pagal senajji kalendorių) dvarininko šeimoje. Tẻvas Apolonas Radus-Zenkavičius buvo valstybės patarejjas, nuo $1868 \mathrm{~m}$. Raseinių apskrityje Bakaičių kaime valdè 152 dešimtines žemės ir miško. 1892 m. aštuoniolikmetis L. Radus-Zenkavičius baigė mokslus Polocko kadetų korpuse ${ }^{5}$ ir įstojo ị Pavelo karo mokyklą Sankt Peterburge. Ją baigęs ir gavęs paporučikio laipsnị, tarnavo 29-ojoje artilerijos brigadoje Rygoje. 1897 m. ìstojo ị Nikolajaus generalinio štabo akademiją, ją baigé 1900 m. štabskapitonu. 1901 m. buvo paskirtas ị Vilniaus karo apygardos štabą, vèliau - 170-ojo Molodečno pulko kuopos vadu. Rusijos-Japonijos karo metu pakeltas ị papulkininkius. 1905-1912 m. èjo 3-iojo korpuso Vilniuje štabo viršininko pareigas, vèliau paaukštintas - suteikus pulkininko laipsnị, paskirtas 27-osios pėstininkų divizijos štabo viršininku. Pirmojo pasaulinio karo metu kovojo Rytų Prūsijoje, vadovavo pulkui, divizijos štabui, divizijai ir armijos štabui, o $1916 \mathrm{~m}$. buvo pakeltas į generolus majorus. Po bolševikų perversmo 1918-1920 m. tarnavo Raudonosios armijos Generalinio štabo Karo istorijos skyriuje, nuo 1920 m. dirbo Lietuvos atstovybeje Maskvoje, $1921 \mathrm{~m}$. grịžo ị Lietuvą ${ }^{6}$.

Lietuvos kariuomeneje generolas tarnavo neilgai - tik 7 metus - nuo $1921 \mathrm{~m}$. vasario 14 d. iki 1928 m. kovo 1 d., tačiau paliko ryškų pẻdsaką. Ejo generolo ypatingiesiems reikalams prie krašto apsaugos ministro pareigas, buvo Karo mokslo skyriaus viršininkas, Aukštụjų karininkų kursų viršininkas, Generalinio štabo viršininkas, Vyriausiojo štabo viršininkas, nuolatinis Karo tarybos narys, Lietuvos karininkų ramovès seniūnų tarybos narys. Tarnybos metu buvo komandiruotas ị SSRS, Čekoslovakiją, Prancūziją, Šveicariją, Didžiąją Britaniją ir Vokietiją ${ }^{7} 1922$ m. lapkričio 26 - gruodžio $19 \mathrm{~d} .^{8}$ Maskvoje dalyvavo nusiginklavimo konferencijoje $e^{9} 1923$ m. birželị lankèsi Prancūzijoje, kur stebejo didžiulius karinius

\footnotetext{
5 Pociūnas A. Dviejų kariuomenių generolas. Trimitas, 1992, Nr. 1, p. 5.

6 Asevičius V. ir kt. Lietuvos kariuomenes karininkai 1918-1953, t. VI. Vilnius, 2006, p. 202.

7 Tarnybos lapas, 1928 m. kovo 17 d. [dokumento kopiją suteikè gen. L. Radaus-Zenkavičiaus proanūkè kompozitorè Onutė Narbutaitè-Skirmantienè], 1. 1-6.

8 Русская армия в Первой мировой войне [žr. 201310 20]. <http://www.grwar.ru/ persons/persons.html?id=75>.

9 Mūsų delegacija Maskvos nusiginklavimo konferencijon. Karys, 1922, lapkričio 30, Nr. 48 (184), p. 574.
} 
manevrus, o grịžęs ị Lietuvą pasidalijo ịspūdžiais surengtoje viešoje paskaitoje $^{10} .1924 \mathrm{~m}$. pabaigoje dviem ménesiams buvo išvykęs stažuotis $\mathfrak{i}$ Prancūziją, ì „maršalų akademiją"11. Šiuose kursuose dalyvavo 22 užsienio generolai, kartu su gen. L. Radumi-Zenkavičiumi mokèsi ir Suomijos kariuomenès vadas ${ }^{12}$ gen. mjr. Vilho Nenonenas. 1924 m. spalio 27-28 d. generolas lankèsi Briuselyje. Joje padèkojo už tai, kad Belgija prièmė mokytis Lietuvos karininkus, aptarè karininkų rengimo perspektyvas, lankèsi Belgijos karo akademijoje ${ }^{13} .1924$ m. gruodžio 20 d. gen. L. Radų-Zenkavičių maloniai prièmė Belgijos karalius Albertas I, Lietuvos karininkų delegacija padejjo vainiką prie Nežinomo kario kapo, aplankẻ Karo muziejų, Karo mokyklą ir Belgijos kariuomenès 12-ąji artilerijos pulką. Tuo metu Belgijoje studijavo 5 Lietuvos karininkai, už kurių mokslą belgai atsisakè imti mokestit ${ }^{14}$. 1927 m. spalio 20 d. ${ }^{15}$ gen. L. Radus-Zenkavičius išvyko $\mathfrak{i}$ Didžiąją Britaniją ir susitarè dẻl Lietuvos skolos už 1919-1920 m. britų suteiktą karinị turtą - pagal susitarimą Lietuva per 5 metus turejjo sumokèti 150000 svarų sterlingų ${ }^{16}$ (apie 7,35 mln. Lt), nors Didžioji Britanija reikalavo 444068 svarų sterlingų (apie 21,76 mln. Lt) ${ }^{17} .1928 \mathrm{~m}$. vizito Didžiojoje Britanijoje metu generolas susipažino su šios šalies kariuomene ir jos motorizuotosiomis pajègomis, tankų modeliais, jų panaudojimo galimybėmis $^{18}$. Gen. L. Radus-Zenkavičius, Karo mokslų draugijos iniciatorius ir ¡kūrẻjas, buvo šios draugijos pirmininkas nuo ịsteigimo iki $1925 \mathrm{~m}$. liepos ménesio ${ }^{19}$. Lietuvos kariuomenejje 1922 m. buvo apdovanotas Didžiosios

10 Lietuvos karo misijos išvažiavimas ị manevrus Prancūzijoje. Karys, 1923, birželio 14-20, Nr. 24 (212), p. 282; Lietuvos karinè misija Prancūzijoje. Karys, 1923, rugpjūčio 28-liepos 1, Nr. 26 (214), p. 308; Mūsų karo misija Prancūzijoj. Karys, 1923, rugpjūčio 1-7, Nr. 31 (219), p. 358-359.

11 Kariuomenès gyvenimas. Karys, 1924, spalio 30-lapkričio 5, Nr. 44 (284), p. 362.

12 Karo kronika. Karys, 1925, sausio 8-14, Nr. 2 (294), p. 11.

13 Kariuomenès gyvenimas. Karys, 1924, lapkričio 20-26, Nr. 47 (287), p. 385.

14 Kariuomenès gyvenimas. Karys, 1925, sausio 15-21, Nr. 3 (295), p. 21.

15 Ažubalis A. ir kt. Karo pedagogika Lietuvoje (1918-1940 m.). Vilnius, 2007, p. 130.

16 Itvairios žinios. Trimitas, 1927, lapkričio 24, Nr. 46, p. 1458.

17 Liubinas V. Mūsų ginklai 1919-1920 metais. Mūsų žinynas, 1938, t. XXXV, Nr. 11-12, p. $772-773$.

18 Anglų kariuomenè bei motorizuotoji divizija. Kardas, 1928, vasario 29, Nr. 6 (102), p. 100.

19 Mūsų kariuomenès gyvenimas. Kardas, 1928, kovo 10, Nr. 7 (103), p. 119. 


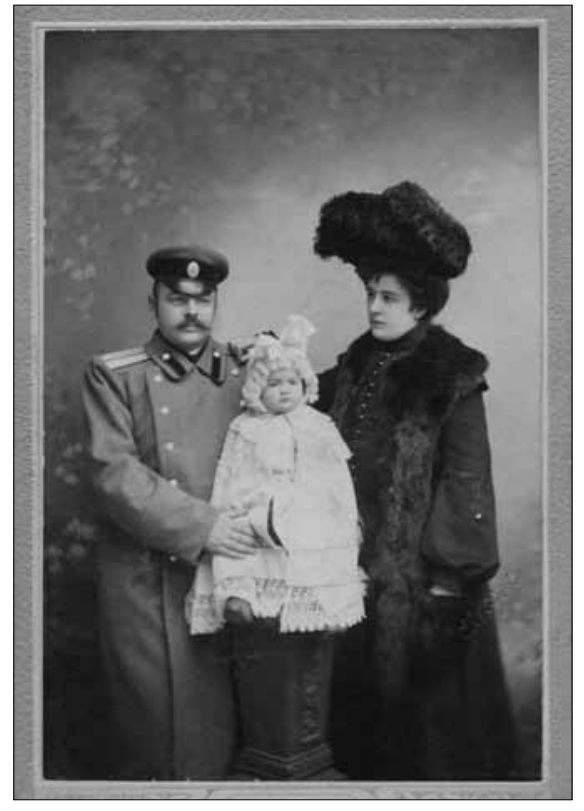

Karininkas Leonas Radus-Zenkavičius su dukra Olga Radus-Zenkavičaite ir žmona Liuba Radus-Zenkavičiene Vilniuje $1905 \mathrm{~m}$.

Asmeninio Onutès Narbutaitè-

Skirmantienès šeimos archyvo nuotrauka

Britanijos Šv. Mykolo ir šv. Jurgio ordinu (The Most Distinguished Order of Saint Michael and Saint George $)^{20}, 1924$ m. - II rūšies 3-iojo laipsnio Vyčio Kryžiumi, 1924 m. - Rumunijos valstybès aukščiausio laipsnio karininkų Coroana Romanie ordinu su žvaigžde ir kardais ${ }^{21}, 1924$ m. gegužès 10 d. Čekoslovakijos kariniu ordinu Československý válečný kř́žžz2, 1928 m. už ypatingus nuopelnus Lietuvai - Didžiojo Lietuvos kunigaikščio Gedimino 1-ojo laipsnio ordinu ${ }^{23}$.

$1921 \mathrm{~m}$. spaudoje analizuojant sutinkamųjų kautynių taktiką buvo kalbama ir apie partizanini pasipriešinimą: „Kai kurie mano, kad mūsų [Lietuvos - V. J.] karo lauko sąlygos, jègų santykiavimas turi priversti mus

\footnotetext{
20 Anglų aukšta dovana. Karys, 1922, lapkričio 30, Nr. 48 (184), p. 574.

21 Iš kariuomenès gyvenimo. Karys, 1924, sausio 24-31, Nr. 4 (244), p. 34.

22 Čekoslovakų dovana. Karys, 1924, gegužès 15-21, Nr. 20 (260), p. 170; Garbinga Čekoslovakų dovana. Karys, 1924, gegužès 29-birželio 4, Nr. 22 (262), p. 185; Čekoslovakų ir mūsų karininkų apdovanojimas karo ordinais. Kardas, 1926, kovo 10, Nr. 7 (31), p. 103. 23 Tarnybos lapas, 1928 m. kovo 17 d., 1. 1-6; Ažubalis A. ir kt. Karo pedagogika Lietuvoje (1918-1940 m.). Vilnius, 2007, p. 112.
} 
atsisakyti nuo kautynių vedimo šių dienų manevrų karo sąlygomis ir imtis partizanų veikimo būdų, veikiant mažomis rinktinèmis, batalionais ir net kuopomis operuojant priešininko užpakaly, ardant jo susisiekimą, darant netikètus puolimus ir vengiant veikti didelèmis suspiestomis dalimis. Galima tikrai pasakyti, kad toks veikimo būdas nepadarys mus nugalètojais. Nekalbant jau apie tai, kad ne visur mes rasime vietos gyventojų užuojautos, be kurios partizanų veikimo sẻkmingumas nèra galimas, - tie veiksmai niekad dar nèra davę sprendžiamų rezultatų, t. y. jie negali sunaikinti priešininko jègas. <...> Partizanų karas, kaip savarankiškas veikimo būdas, negali priversti priešininką atsisakyti nuo priešinimosi, o per tai nesuteikia pergalès. <...> Partizanų karas gali tiktai papildyti lauko karą suspiestomis jègomis. " 24 Taigi pripažinta partizaninio karo svarba ir teisingai konstatuota, kad sumušti reguliariųjų priešo pajègų ir pasiekti kare pergalę partizanai vieni patys negalejjo, tam reikejjo ir reguliariųjų pajėgų smūgio. Teikti 1812 m. Rusijos-Prancūzijos, Rusijos karo Kaukaze XIX a., JAV pilietinio karo, 1920 m. Lenkijos-Rusijos karo pavyzdžiaii ${ }^{25}$. Tačiau kartu svarbu pabrèžti, kad neįvertinta tai, kad reguliarioji kariuomenè sunkiai galejo ịveikti partizanų būrius.

Perimant Vakarų Europos valstybių karo mokyklų patirtį buvo formuojamas ir nacionalinis požiūris ił karybą, nes skirtingos geopolitinès sąlygos, valstybių pajègumai vertẻ ieškoti savų sprendimų saugumui užtikrinti, kurti tautinę karo doktriną. 1922 m. balandžio 27-28 d. vyko Lietuvos kariuomenès vadų suvažiavimas. Jo tikslas buvo aptarti Lietuvos karo doktrinos projektą. Susirinkę vadai svarstė gen. L. Radaus-Zenkavičiaus parengtą Lietuvos karo doktrinos projektą, iš protokolo galima spęsti, kad pakeitimai buvo nežymūs, o minèto dokumento pagrindu turejo būti parengti nauji Rikiuotes ir Lauko tarnybos statutai ${ }^{26}$. Nepriklausomybès kovu metu ir po jų Lietuvos kariuomenè rèmèsi Rusijos imperijos kariuome-

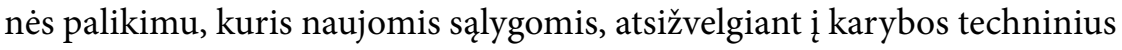

24 [Černiveckis] Susitinkamos kautynès. Karys, 1921, rugsèjo 22, Nr. 38 (122), p. $442-$ 443.

25 Ten pat.

261922 m. balandžio 27-28 d. divizijų vadų suvažiavimo protokolas. $L C V A$, f. 929, ap. 3, b. $445,1.159-163$. 
pokyčius ir vietos sąlygų ypatybes, Lietuvai netiko ${ }^{27}$. Dokumente aptarti kariuomenès komplektavimo, organizavimo, apginklavimo, moralès ir mokymo klausimai, atskirai - skyrius Taktikos doktrina (pagal dokumento turini tai tiesiog kautynių taktika), kuriam skirti 27 puslapiai iš 57 karo doktrinos mašinraščio puslapių, t. y. apie $47 \%{ }^{28}$. Didžiulis demesys buvo skirtas karių auklejjimui ir mokymui, nes „kad nugalètum, reikia trokšti nugalèti ir nesiskaityti su savo gyvybe. Visų pirma reikia mokèti padaryti priešui kuo didžiausių nuostolių, o sau, sumaniai vadovaujat kautynèms, kuo mažiau“29. Akcentuotas patriotinis ir tautinis auklejimas, kuris laiduotų aukštą karių motyvaciją, o religija padètų užtikrinti moralinị kario pasirengimą, kad mokymas turi būti standartizuotas ir vienodas visoje ka-

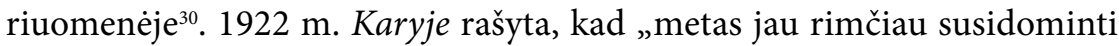
karo mokslu ir menu, jų evoliucija, paskutiniu jų žodžiu; metas pagrindinai ištirti savo dalių kautynès ir žygiai, kad pasisèmus mokslo ateities žygiams. Metas jau rengti dirvą naujai savajai karo doktrinai, kuri galima bus įvesti, kai mūsų karininkų kadras bus bendrai karo moksle pasiruošęs ir bus Lietuvos karo veiksmų esmę ir lietuvio kario psichologiją pažinęs “"31. Dèl to būtina: 1) kad rikiuotès karininkai nuolatos rengtų referatus, klausytų paskaitų, skaitytų pranešimus, organizuotų taktikos teorines pratybas; 2) skirti lèšų karinèms bibliotekoms kurti, literatūrai užsienyje pirkti. Be to, pabrèžta, jog karininkai privalo mokytis užsienio kalbų, kad galètų domètis karo mokslo naujovemis ${ }^{32}$.

1922 m. parengus karo doktriną, o 1923 m. išleidus naują statutą, neatsitiktinai $1923 \mathrm{~m}$. liepos $13 \mathrm{~d}$. buvo surengti pavyzdiniai kariuomenès manevrai. Už jų organizavimą padèka buvo pareikšta būtent gen. L. Radui-Zenkavičiui ${ }^{33}$. Šių manevrų organizavimą galima susieti ir su minèta

27 Dèl karo doktrinos prièmimo Lietuvos kariuomenèje, 1922 m. gen. L. Radus-Zenkavičius. $L C V A$, f. 929 , ap. 3, b. 445, 1. 16-16 apv. 1.

28 Ten pat, 1. 31-44 apv. 1.

29 Ten pat, apv. 1. 24.

30 Dèl karo doktrinos priemimo Lietuvos kariuomenèje, 1922 m. gen. L. Radus-Zenkavičius. $L C V A$, f. 929 , ap. 3, b. 445, 1. 24-30 apv. 1.

31 V. J. Pasirūpinkim savimi. Karys, 1922, lapkričio 30, Nr. 48 (184), p. 569.

32 Ten pat.

33 Padèka. Karys, 1923, rugpjūčio 10-17, Nr. 32 (220), p. 378. 
išvyka 1923 m. birželị stebèti manevrų ị Prancūziją, nes ten igyta patirtis praktiškai buvo taikoma Lietuvos kariuomeneje. Analogiškai pavyzdiniai Aukštųjų karininkų kursų viršininko gen. L. Radaus-Zenkavičiaus ir jo kolegų organizuoti manevrai vyko 1924 m. rugpjūčio 12-13 d., juose dalyvavo Kauno igulos daliniai ir Karo mokykla. Jų metu veikè pėstininkai ir artilerija, buvo naudojami tankai, manevrus stebejo Prancūzijos karo atašè ${ }^{34} .1925$ m. liepos 13 d. gen. L. Radus-Zenkavičius IV forto ir Rokų kaimo rajone organizavo kariuomenès „transmisijos“ manevrus ${ }^{35}$.

Karo doktrinoje buvo numatyta generalinio štabo karininkams rengti Lietuvoje ịsteigti aukštąją generalinio štabo karininkų mokyklą, nes tuo tikslu karininkus siųsti ị užsienị brangiai kainavo ir - dar svarbiau - tokiu atveju negalejo būti formuojamas tautinis generalinis štabas, kuriama lietuviška karybos doktrina ir terminija. Lietuvos aukštoji karo mokykla galëjo užtikrinti nuoseklų tautinès karo doktrinos diegimą kariuomenèje, galimybę ją perprasti karininkijai ir tautai ${ }^{36} .1924 \mathrm{~m}$. Lietuvos karo mokymo ịstaigų atstovų pasitarime buvo svarstomas „karo mokymo ịstaigose doktrinos vienodumas“, buvo nutarta, siekiant ji išlaikyti, pasitelkti geriausius savo sričių specialistus ir leisti vienai mokymo ịstaigai lektorius kviesti iš kitos institucijos, pvz., taktikos lektorius - iš Aukštųjų karininkų kursų $^{37}$. 1927 m. gen. L. Radus-Zenkavičius pasiūlè Aukštuosiuose karininkų kursuose steigti generalinio štabo skyrių, nes nuogąstavo, kad, to nepadarius, bus sunku suvienodinti skirtingose užsienio šalyse studijuojančių karininkų požiūrị ị karybą ir kariavimo metodus, be to, „galutinai nustatyti savo karo doktriną ir ją igyvendinti mūsų [Lietuvos - V. J.]

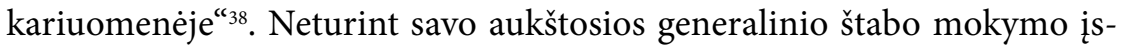
taigos, nebus galima sudaryti gerai, vienodai parengtų generalinio štabo

\footnotetext{
34 Krašto aps. Ministerio įsakymas Nr. 86 iš 1924 m. rugp. 19 d. Karys, 1924, rugsèjo 11-17, Nr. 37 (277), p. 302-304.

35 Transmisijos manevrai. Karys, 1925, liepos 23-29, Nr. 30 (322), p. 234-235.

36 Dèl karo doktrinos prièmimo Lietuvos kariuomenejje, 1922 m. gen. L. Radus-Zenkavičius. $L C V A$, f. 929, ap. 3, b. 445, 1. 19-21 apv. 1.

37 Karo mokymo įstaigų atstovų posèdžio $1924 \mathrm{~m}$. spalio $18 \mathrm{~d}$. protokolas. LCVA, f. 1451, ap. 1, b. 17, 1. 4-5.

38 Gen. L. Radaus-Zenkavičiaus 1927 m. balandžio 28 d. raportas Vyriausiojo štabo viršininkui. $L C V A$, f. 1451, ap. 1, b. 33, 1. 11.
} 
karininkų korpuso. Jo manymu, ị generalinio štabo skyrių reikètų priimti 3-4 m. rikiuotès daliniuose tarnavusius karininkus ir juos mokyti $2 \mathrm{~m} \cdot{ }^{39}$ Skirtingo karininku parengimo lygio problema egzistavo, nes pasitaikydavo, kad jauni karininkai, baigę Aukštuosius karininkų kursus ir grị̌zę i dalinius, nerasdavo bendros kalbos su savo vadais, nesimokiusiais šiuose kursuose. Be to, kildavo sunkumų ir užsienyje aukštąsias generalinio štabo mokyklas baigusiems karininkams, tarnaujantiems Lietuvos kariuomenès štabe, nes jų siųstų i dalinius ịsakymų vadai nesuprasdavo ir negalèdavo vykdyti. Sprendžiant šią problemą buvo nutarta organizuoti specialius kursus vyresniesiems karininkams, t. y. divizijų, pulkų ir jų štabų vadams, siekiant supažindinti su visomis karybos naujovėmis, suvienodinti jų pažiūras ir pasirengimą ${ }^{40}$. Būtinybę steigti generalinio štabo karininkų skyrių generolas argumentavo tuo, kad: 1) Aukštieji karininkų kursai taip sustiprejjo, kad galètų sudaryti generalinio štabo skyrių; 2) jau yra pakankamai lektorių ir instruktorių, igijusių aukštąjł karinị išsilavinimą; 3) neturint generalinio štabo kursų, labai sunku: a) suvienodinti karininkų, studijavusių skirtingose valstybèse, pažiūras; b) galutinai nustatyti ir kariuomenèje igyvendinti karo doktriną; 4) be generalinio štabo kursų neįmanoma suformuoti vienodai parengto ir Lietuvos sąlygomis tinkamo generalinio štabo karininkų korpuso. Tačiau generalinio štabo karininkų skyrius buvo isteigtas tik $1931 \mathrm{~m}^{41}$

1925 m., išleidžiant V Aukštųjų karininkų kursų laidą, gen. L. RadusZenkavičius pabrèžè, kad „nors karo mašinizacija vis didèja ir karo technika be paliovos keičia kautynių formas, bet pirmutinis ir svarbiausias karo elementas - žmogus lieka tas pats su visomis savo žemomis ir kilniomis savybėmis“" ${ }^{42}$. Po metų aptariant Aukštųjų karininkų kursų svarbą diegiant karo doktriną, buvo prisiminta generolo mintis, kad ,juo kultūringesnè ir savaimingesnè tauta, <... juo ryškiau bendram ir kariškam gyvenime pasireiškia jos savybès ir ypatumai, juo geriau organizuotas jos politiškas ir

\footnotetext{
39 Ten pat.

40 Aukštesniųjų karininkų kursų viršininko 1927 m. gruodžio 27 d. raportas KAM. LCVA, f. 1451, ap. 1, b. 33, 1. 88.

41 Ažubalis A. ir kt. Karo pedagogika Lietuvoje (1918-1940 m.). Vilnius, 2007, p. 144.

42 Aukštųjų karininkų D. L. K. Vytauto kursų V laidos išleistuvėms paminèti. Kardas, 1925, rugpjūčio 1, Nr. 14, p. 16.
} 
socialinis sutvarkymas, juo daugiau, pagalios, jai teko ir tenka kovoti, - tuo ryškiau ir aiškiau pasireikš jos doktrina, tuo labiau ji atitiks tautos esmę "43. Taigi pabrèžta asmens ir tautos svarba formuojant karinę doktriną. Apskritai generolas daug prisidejjo prie Auštųjų karininkų kursų veiklos plètros ne tik kaip vadovas, bet ir kaip dėstytojas. Kursuose karininkams buvo diegiama Lietuvos kariuomenès karo doktrina ${ }^{44}$.

Be minètų Aukštųjų karininkų kursų ${ }^{45}$, karinès doktrinos klausimais buvo bandoma dirbti ir Karo mokslų draugijoje ${ }^{46}$. Jos tikslas buvo jungti asmenis, kurie „karo mokslu domisi, kad jie galètų tobulintis karo dalykuose, žiūrint jų progreso ir bendrai platina karo žinias Lietuvos kariuomenès ir visuomenès tarpe ${ }^{\text {“ }_{47}} .1927 \mathrm{~m}$. naujame draugijos statute šis tikslas kiek platesniame kontekste buvo pakartotas ${ }^{48}$. Iš esmès karo doktrina Karo mokslų draugijoje rūpinosi Taktikos sekcija, kurios pagrindinis uždavinys buvo karininkų bei puskarininkių mokymas ${ }^{49}$. Karo mokslo draugijos centro valdyba $1925 \mathrm{~m}$. vasario $20 \mathrm{~d}$. buvo nutarusi surengti mokslini pasitarimą tema Tinkamiausia Lietuvos karo sistema, jo metu turejo būti pristatytos Prancūzijos, Belgijos, Čekoslovakijos ir Rusijos karybos sistemos, aptarta bendra tokios sistemos ideja, karo tarnybos sąlygos, mobilizacijos tvarka ${ }^{50}$. Panašios iniciatyvos karinès vadovybès, matyt, nebuvo palankiai sutiktos. Po keleto dienų, priemus ši draugijos nutarimą, III karo apygardos viršininkas kariuomenès vadui raportavo, kad „nustatyti valstybès karo sistemą yra užduotis tik pačios vyriausybès. Karo siste-

\footnotetext{
43 Aukštieji karininkų D. L. K. Vytauto kursai ir jų reikšmė mūsų kariuomenei. Kardas, 1926, rugpjūčio 20, Nr. 23 (47), p. 355.

44 Plačiau apie gen. L. Radaus-Zenkavičiaus veiklą Aukštuosiuose karininkų kursuose ir karo doktrinos diegimą žr.: Ažubalis A. ir kt. Karo pedagogika Lietuvoje (1918-1940 m.). Vilnius, 2007. 480 p.

45 Plačiau apie kursų steigimą ir veiklą žr.: Štencelis, Aukštieji karininkų D. L. K. Vytauto kursai. Mūsǔ žinynas, 1928, t. XV, Nr. 45, p. 389-426.

46 Plačiau apie draugijos steigimą ir veiklą žr.: Navakas, Karo mokslų draugija. Mūsų žinynas, 1928, t. XV, Nr. 45, p. 621-628.

47 Karo mokslų draugijos statutas, 1923 m. lapkričio 26 d. $L C V A$, f. 889, ap. 1, b. 7, 1. 18.

48 Karo mokslų draugijos statutas, 1927 m. kovo 5 d. LCVA, f. 889, ap. 1, b. 7, 1. 10.

49 [Dokumentas be pavadinimo] 1925 m. LCVA, f. 889, ap. 1, b. 24, 1. 5-5 apv. 1.

50 Karo mokslo draugijos centro valdybos 1925 m. vasario 20 d. protokolas. $L C V A$, f. 929, ap. 3, b. $526,1.9$.
} 
ma turi būti suderinta su bendru valstybès aparatu, su šalies politika ir t. t. Tokius klausimus gali spręsti tik kompetentiški asmenys, stovintieji priešaky mūsų valdžios, nes jie tik teisètai gali šiuos klausimus spręsti, turint tam tikrų reikalingų žinių “51. Raportas buvo išgirstas ir 1925 m. kovo $21 \mathrm{~d}$. kariuomenės vadas gen. Silvestras Žukauskas, vertindamas draugijos iniciatyvas, konstatavo, kad ši pusiau oficiali organizacija negali karinio rengimo ir organizacinejje srityse imtis kokių nors veiksmų, nesuderinusi su kariuomenès vadu ${ }^{52}$.

1927 m. sausio mèn. Lietuvos kariuomenès Vyriausiojo štabo Operacijų skyrius konstatavo, kad „karo doktrinos nustatymas ir tobulinimas iki 1926 m. buvo monopolizuotas de facto Auštųjų karininkų kursuose. Nuo 1926 m. rudens ši funkcija buvo pradèta perimti Operacijų skyriaus, artimoje pačio Vyriausiojo štabo viršininko priežiūroje. Esamojo padejimo išsiaiškinimui 1926 m. rudenị buvo surengta eilè pratimų. Jų pasekmèje buvo nuspręsta 1927 m. pradžioje surengti Aukštųjų viršininkų kursus, kurių pirmaeiliu tikslu buvo, be paprasto klausytojams žinių suteikimo, nuodugnių lektorių studijų ir nuomonių pasikeitimo keliu suprecizuoti pažiūras ị visus svarbiausius karo lauko darbus. Tos pažiūros tinkamai formuluotos ir gultų ị mūsų doktrinos pagrindą. Šiam darbui organizuoti žymi dalis teko ir turejjo tekti ateityje operacijų skyriui. Atskirai, be to, operacijų skyriaus buvo peržiūrèta eilè statutų projektų ir duota apie juos nuomonè. Artimoje ateityje operacijų skyrius turètų užsiimti paruošimu štabų tarnybos statuto ir dabar veikiančio pèstininkų statuto peržiūrẻjimu“"53.

1922-1928 m. gen. L. Radus-Zenkavičius vadovavo Aukštiesiems karininkų kursams, aktyviai dalyvavo Karo mokslų draugijos veikloje ${ }^{54}$, taigi generolo indèlis formuojant Lietuvos karo doktriną tarpukariu neabejotinai svarus. Savo karybos idejjas L. Radus-Zenkavičius išdèstė Lietuvoje

51 III karo apygardos viršininko $1925 \mathrm{~m}$. vasario 26 d. raportas kariuomenès vadui. $L C V A$, f. 929, ap. 3, b. 526, 1. 12.

52 Kariuomenès vado įsakymas karo apygardų vadams ir draugijos pirmininkui, $1925 \mathrm{~m}$. kovo 21 d. LCVA, f. 929, ap. 3, b. 526, 1. 15.

53 Operacijų skyriaus sutvarkymo ir darbo apžvalga, 1927 m. sausis. LCVA, f. 929, ap. 3, b. $579,1.1-7$.

54 Asevičius V. ir kt. Lietuvos kariuomenés karininkai 1918-1953, t. VI. Vilnius, 2006, p. 202. 
išleistose knygose $\mathrm{e}^{55}$ ir straipsniuose, išspausdintuose karinejje periodikoje, ypač Mūsų žinyne $e^{56} .1927$ m. jis su specialia misija lankèsi Didžiojoje Britanijoje. Kelionès metu gavo kvietimą bendradarbiauti britų karinèje periodikoje, žurnale The Cavalry Journal buvo išspausdintas L. Radaus-Zenkavičiaus straipsnis Rusu kavalerija Rytprūsiuose ${ }^{57}$. Be to, 1914-1920 m., jis paskelbė keletą straipsnių rusų kalba ${ }^{58}$.

55 Radus-Zenkavičius L. Susitinkamuju kautynių bruožai. Kaunas, 1921, 132 p.; RadusZenkavičius L. Karas; Karo galybe; Karo mokslas. Kaunas, 1922, 47 p.; Radus-Zenkavičius L. Kautyniu skyrius ir jo vartojimas kautynese. Kaunas, 1922, 44 p.; Radus-Zenkavičius L. Kautyniu skyrius ir jo vartojimas kautynèse: suderinta su naujo péstininku rikiuotés statuto projektu. Kaunas, 1922, 104 p.; Radus-Zenkavičius L. Péstininku taktikos bruožai. Kaunas, 1923, 196 p.; Radus-Zenkavičius L. Trumpas Didžiojo karo eskizas. Kaunas, 1924, 296 p.; Radus-Zenkavičius L. Vietos reikšme taktikai. Kaunas, 1925, 8 p.; Radus-Zenkavičius L. Kaip mažas dalis rengti kautynems. Kaunas, 1926, 30 p.

56 Radus-Zenkavičius L. Karas, karo galybė, karo mokslas. Mūsų žinynas, 1921, t. I, Nr. 2, p. 3-25; Radus-Zenkavičius L. Prancūzų pèstininkų organizacija ir jos puolimo formos lauko kautynèse. Mūsų žinynas, 1921, t. I, Nr. 3, p. 3-34; Radus-Zenkavičius L. Šių laikų artilerija ir jos vartojimas manevrų kare. Mūsu žinynas, 1922, t. II, Nr. 1, p. 3-34; Radus-Zenkavičius L. Pirmoji lenkų armijos karo doktrina. Mūsų žinynas, 1922, t II, Nr. 2, p. 215-244; Radus-Zenkavičius L. Trumpas didžiojo karo eskizas. 1915 metų kampanija. Mūsų žinynas, 1922, t. II, Nr. 3, p. 522-559; Radus-Zenkavičius L. Trumpas Didžiojo karo eskizas. 1915 metų kampanija (3 nr. tęsinys). Mūsǔ žinynas, 1922, t. III, Nr. 3, p. 42-61; Radus-Zenkavičius L. Kautynių skyrius ir jo vartojimas kautynèse. Mūsu žinynas, 1922, t. III, Nr. 8, p. 235-276; Radus-Zenkavičius L. Ginamosios pėstininkų kautynès lauko kare. Mūsų žinynas, 1922, t. III, Nr. 9, p. 495-501; Radus-Zenkavičius L. Trumpas Didžiojo karo eskizas. 1916 metų kampanija. Mūsų žinynas, 1922, t. III, Nr. 9, p. 574-607; Radus-Zenkavičius L. Trumpas Didžiojo karo eskizas. 1916 metų kampanija (Mūsų žinyno 9 nr. tęsinys). Mūsų žinynas, 1923, t. IV, Nr. 10, p. 48-73; Radus-Zenkavičius L. Pèstininkų apginklavimas ir kautynių priemonès. Mūsų žinynas, 1923, t. IV, Nr. 11, p. 203-222; Radus-Zenkavičius L. Pėstininkų parengimas. Mūsu žinynas, 1923, t. IV, Nr. 12, p. 432-447; Radus-Zenkavičius L. Trumpas Didžiojo karo eskizas. 1917 metų kampanija. Mūsų žinynas, 1923, t. VI, Nr. 17, p. 326-349; Radus-Zenkavičius L. Prancūzų ir vokiečių pėstininkų karo doktrina. Mūsų žinynas, 1925, t. VIII, Nr. 23, p. 259-271; Radus-Zenkavičius L. Šaudymo planas ir amunicijos tiekimas ginamosiose kautynèse. Mūsu žinynas, 1925, t. VIII, Nr. 24, p. 457-470; Radus-Zenkavičius L.Kontakto sudarymas. Mūsu žinynas, 1925, t. IX, Nr. 25, p. 21-28; Radus-Zenkavičius L. Vietos reikšmè taktikai. Mūsǔ žinynas, 1925, t. IX, Nr. 27, p. 401-408; Radus-Zenkavičius L. Lodžiaus operacija, kaip klasiškas prasilaužimo pavyzdys. Mūsų žinynas, 1926, t. X, Nr. 30, p. 353-375.

57 Mūsų generolo rašiniai anglų karo spaudoje. Karys, 1927, gruodžio 20-31, Nr. 51-52 (447-448), p. 493.

58 Русская армия в Первой мировой войне [žr. 201310 20]. <http://www.grwar.ru/ persons/persons.html?id=75>. 


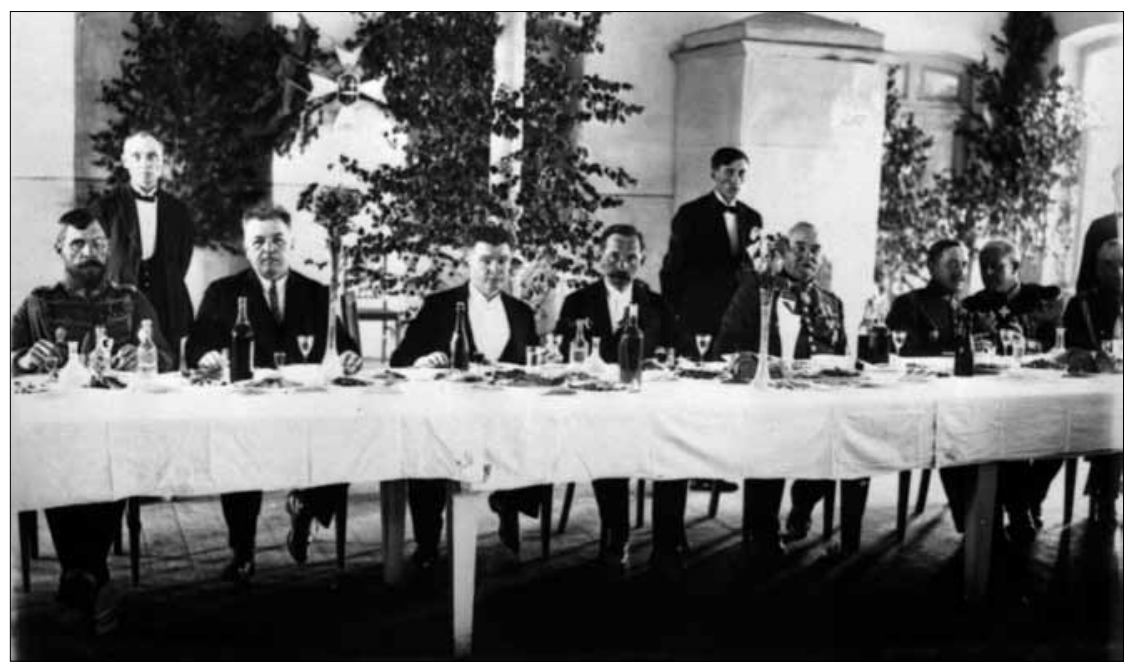

1927 m. karininkų išleistuvių pietūs. Iš kairès sèdi: plk. Povilas Plechavičius, neatpažintas asmuo, Augustinas Voldemaras, Antanas Smetona, gen. Leonas Radus-Zenkavičius, plk. Teodoras Daukantas, neatpažintas asmuo. Asmeninio Onutès Narbutaitès-Skirmantienés šeimos archyvo nuotrauka

Galiausiai 1928 m. prezidentas Antanas Smetona, išleisdamas gen. L. Radų-Zenkavičių ị atsargą, pažymèjo: „Atsisveikindamas su Tamsta, randu reikalingu paminèti Tamstos, Pone Generole, tuos nuopelnus Lietuvai, kuriuos padarète per kelerių metų tarnybą Lietuvos kariuomeneje. Tamstos rūpesniu ir sumanumu ịvesta kariuomenèje nauja karo doktrina, reikiamoje aukštumoje pastatytas taktikos mokymas kariuomenès dalyse, duota gerų pavyzdžių manevrams vesti, suorganizuoti ir gerai pastatyti Aukštieji Karininkų Didžiojo Lietuvos Kunigaikščio Vytauto Kursai. Taip pat negaliu paminèti, jog Tamstos dèka yra palankiai mums sutvarkyta Lietuvos karo skola su Anglija. Už tuos darbus reiškiu Tamstai, Pone Generole, gilios padekos. “59

Atsisveikindamas su kariuomene ir gen. št. plk. Vladui Skorupskiui perleisdamas vadovavimą Aukštiesiems karininkų kursams, generolas pažymejjo: „Prieš septynerius metus man [gen. L. Radui-Zenkavičiui - V. J.]

59 Mūsų kariuomenès gyvenimas. Kardas, 1928, kovo 10, Nr. 7 (103), p. 119. 
teko didelè garbẻ būti pašauktam sukurti pirmuosius Lietuvos kariuomenès karininkams lavintis kursus. Apystovos buvo nepaprastai sunkios: nebuvo nei lektorių, nei knygų, nei kitų reikalingų priemonių, nei butų... Viskas reikejjo kurti iš nieko. Laikui bėgant, ačiū būreliui žmonių, atsidavusių karo mokslo darbui, visas kliūtis pavyko nugalèti ir sukurti kursus, kurie savo mokslo metodais nesiskiria nuo kitose Europos valstybėse esančiu karininkų kursų. Ta proga turiu <...> palinkèti <..> kad jų [kursų - V. J.] pamatuose amžinai pasiliktų dabar esantieji pradai: auklejjime - tèvynès meilé, lavinime - Europoje priimti mokslo metodai ir karininkų elgesyje - garbingumas ir džentelmeniškumas. " ${ }^{60} \mathrm{~V}$. Skorupskis pažymejjo, kad jo tikslas buvo „pastatyti tiltą lietuviškai karo doktrinai, kurios steigejai yra karininkai, kurie jau baigė ir kurie dar baigs Aukštuosius Karininku Kursus, kad pastatytų šulą, ỉ nieką neatsižvelgiant, tą darbą užbaigti, kad visos mūsų kariuomenès korpas būtų viendvasis ir vienmintis, kad kursai išauklètų karininkus, kurie irgi būtų viendvasiai ir vienminčiai“61.

1928 m. kovo 1 d. Karininkų ramoveje išeinančiam į atsargą generolui buvo surengtos išleistuvès, jose dalyvavo A. Smetona, ministras pirmininkas Augustinas Voldemaras, krašto apsaugos ministras plk. Teodoras Daukantas, kiti aukštieji karininkai, Kauno igulos dalinių vadai ${ }^{62}$. Išejjusio $\mathfrak{i}$ atsarga generolo aktyvi veikla nesibaigè, $1928 \mathrm{~m}$. kovo $30 \mathrm{~d}$. gen. L. Radus-Zenkavičius kaip karinis ekspertas kartu su A. Voldemaru, Dovu Zauniumi, Vaclovu Sidzikausku ir kitais delegacijos nariais vyko ił derybas su Lenkija Karaliaučiuje ${ }^{63} .1928$ m. gegužès mèn. buvo derybų su Lenkija dèl karo nuostolių atlyginimo pakomisès pirmininkas ${ }^{64}$.

1928 m. L. Radus-Zenkavičius su šeima persikèlè gyventi $\mathfrak{i}$ ịsigytą Čiučelių dvarą, $3 \mathrm{~km}$ nuo Vilkyškių. $1907 \mathrm{~m}$. duomenimis, dvarą sudaré 190 ha valda, iš jų - 120 ha ariamos žemès, 25 ha pievų ir 10 ha miško ${ }^{65}$. Sovietams okupavus Lietuvą, 1944 m. po nesèkmingo bandymo pasitrauk-

\footnotetext{
60 Iš Aukšt. Karininkų D. L. K. Vytauto Kursų gyvenimo. Karys, 1928, vasario 17-kovo 6, Nr. 9-10 (457-458), p. 171-172.

61 Ten pat.

62 Mūsų kariuomenès gyvenimas. Kardas, 1928, kovo 10, Nr. 7 (103), p. 119.

63 Kraštas ir visuomenè. Kardas, 1928, kovo 20-30, Nr. 8-9 (104-105), p. 142.

64 Kraštas ir visuomenè. Kardas, 1928, gegužès 10-20, Nr. 13-14 (109-110), p. 209.

65 Meškauskienė R. ir kt. Šilutès ir Pagégių krašto dvarai. Klaipėda, 2010, p. 51-53.
} 
ti ị Vakarus generolas grịžo ị Kauną, čia slapstėsi, o 1946 m. balandžio 12 d. mirè, palaidotas Aukštosios Panemunès kapinėse. Generolo šeima 1949 m. buvo ištremta ị Sibirą ${ }^{66}$. Nepelnytai pamirštas gen. L. Radus-Zenkavičius nepateko ị 1998 m. Vidmanto Jankausko išleistą knygą, kurioje pateikta 30 iškilių tarpukario Lietuvos kariuomenès generolų biografijų ${ }^{67}$. Tarpukariu iš viso Lietuvos kariuomenèje tarnavo 58 generolo laipsnị turintys karininkai ${ }^{68}$. Taigi pirmosios Lietuvos kariuomenès karinès doktrinos autorius gen. L. Radus-Zenkavičius, kurio glausta biografija pateikta karininkų žinyne ${ }^{69}$, priskirtinas prie tų generolų, kurių veiklos tyrimai gali atverti naujus Lietuvos karo istorijos klodus. Gen. L. Radus-Zenkavičius ne tik parengè tarpukario Lietuvos karo doktriną, bet ir aktyviai dirbo diegdamas ją kariuomeneje.

Iteikta 2013 m. rugsejo $27 \mathrm{~d}$.

\footnotetext{
66 Asevičius V. ir kt. Lietuvos kariuomenès karininkai 1918-1953, t. VI. Vilnius, 2006, p. 202.

67 Jankauskas V. Nepriklausomos Lietuvos generolai. I dalis. Vilnius, 1998. 280 p.

68 Pristatyta kilnojamoji paroda „Lietuvos Respublikos kariuomenès generolai 1919-1940 metais“ [žr. 201310 23] < http://kariuomene.kam.lt/lt/kariuomenes_atributika/karo_istorija/vytauto_didziojo_karo_muziejus/parodos_3515/paroda_lietuvos_respublikos_kariuomenes_generolai_19191940_metais.html?pbck=10>.

69 Asevičius V. ir kt. Lietuvos kariuomenés karininkai 1918-1953, t. VI. Vilnius, 2006, p. 202.
} 